\title{
Medical kitsch
}

\section{John Launer}

Turning on the car radio recently, I found myself listening to a well-known London psychiatrist. An interviewer was asking his opinion about a scheme to offer cognitive-behaviour therapy (CBT) to very large numbers of people who have been out of work for a long time because of depression. The scheme has had a lot of publicity in the UK. It been promoted in particular by Lord Richard Layard, an economist with an interest in mental health, and it has won great favour recently with the British government. ${ }^{1}$ The aim is to train several thousand mental health workers in a short space of time to deliver the therapy in centres throughout the country. Supporters of the scheme argue that this will reduce unemployment and hence the volume of claims for incapacity benefit. However, the psychiatrist on the radio-Dr Derek Summerfield from the Maudsley Hospital—was dismissive. He summed up the proposal in a single word: "It is kitsch", he said.

I have never come across the notion of kitsch in medicine or psychology before, but I found the idea helpful. Kitsch, in case you are unfamiliar with the term, is used in the world of art to describe anything that is a cheap and sentimental substitute for an object of true worth. The word is of German and Yiddish origin and implies scraping together something hastily. It was originally applied to cheap imitations of great romantic paintings, sold to the rising bourgeoisie in the nineteenth century, but is nowadays applied to anything tacky and tasteless. Typical examples of kitsch include fridge magnets showing Michelangelo's David, tea towels displaying the Mona Lisa, miniature plastic models of the Taj Mahal, and crucifixes with egg timers on them. What characterises kitsch is a mindless confusion of what is banal, glossy, easy to produce and cheap with what is complex, subtle, painstaking and unique. Milan Kundera, the Czech writer, has argued that kitsch helps us to exclude from view anything that we may have difficulty in coming to terms with. He has

Correspondence to: Dr J Launer, London Department of Postgraduate Dental and Medical Education, Stewart House, 32 Russell Square, London WC1B 5DN, UK; jlauner@londondeanery.ac.uk even proposed that kitsch is an aspect of totalitarian thinking, as it offers us a vision of the world in which "all answers are given in advance and preclude any questions."

Once you start to think about medicine in these terms, it is not hard to see that kitsch is quite a good description of much around us nowadays. Most performance targets in hospitals and general practice arguably count as kitsch-like shorter waiting times in $\mathrm{A} \& \mathrm{E}$ departments or recording everyone's body mass index in surgeries. At first sight, all such targets seem exciting and persuasive, especially to managers and policy makers. The general public also find such targets appealing. Yet, as professionals, we know that the glossy rhetoric behind each target is usually cheap and illusory. We also know that such interventions will inevitably have unintended consequences for individual patients and for the whole system of care. In the messy realities of the health service, an awful lot of people are now being shunted on to in-patient wards unnecessarily, in order to get the waiting room statistics right. Meanwhile, GPs and their staff are wasting hours by the weighing scales and computer screens, with patients who would much rather talk about the problems they came to discuss in the first place. Perhaps only a kitschy view of health, illness and treatment could lead anyone to believe that a single simplistic target would propel everything forward in the same way as a bat hitting a ball.

I also agree with Dr Summerfield's evaluation of mass-produced CBT as kitsch. I am certainly sceptical about any quick fix that purports to address the cumulative factors-genetic, environmental and social - that lead to people becoming significantly depressed. Nor does the evidence convince me that a short course of standardised treatment given by young graduates, after minimal training, can transform people's lives significantly in the long term (although it may well produce enough short-term change to make them tick the right box on questionnaires.) But the apparently facile nature of the scheme, and the lack of compelling evidence, are barely relevant. The Layard proposal, one might say, is simply one among many manifestations of kitsch in medicine, and in public policy. We are surrounded by examples of similarly plausible schemes that have swept aside good practice, with poor evidence, no piloting, and with little support from most practitioners. The appeal of these schemes, like that of kitsch, is immediate but insubstantial.

Kitsch is always superficially attractive, so that opposition to it-whether in art or medicine-will always seem like inflexibility, vested interest or a dislike of the ordinary people. Another problem here is that arguments over kitsch tend to focus on the details, whereas what is at stake is an entire view of how the world works and the scale of both its ugliness and its beauty. When I was at university, I once went to hear a demonstration of a keyboard synthesiser that attempted to reproduce the sounds of an entire symphony orchestra. The resulting noise was tinny and garish, but a friend of mine who was present, and who had little ear for classical music, asked me earnestly if I thought that the machine heralded the end of all live orchestras. How does one start to convey the true meaning of music, or of medicine, in response to such a challenge?

In the case of medicine, I suspect that the answer must lie with good, painstaking science. The best way to argue against kitschy ideas in medicine is probably not with derision and contempt but by appealing for evidence and by demanding a sufficient level of analysis. Systems theory and complexity science may be useful here, because both approaches demand that we widen our perspective, going beyond apparently obvious truths, to the more sophisticated realities that may lie behind them. Similarly, qualitative research may help where numbers fail, on Einstein's famous principle that what counts cannot necessarily be counted, and what can be counted does not necessarily count. We may lose some battles along the way, because analysis and good evidence take longer to amass than plausible slogans. However, the only professional option must surely be to fight the war in a professional way, frustrating as that may be.

The biggest danger of kitsch in medicine may be that we as doctors become indoctrinated by it ourselves. As with kitschy art and artists, the process is presumably an insidious one, with practitioners gradually becoming seduced by the simplicity and rewards of kitsch so that they first become apologists ("it's harmless and it keeps the majority of people happy") and then passionate 
proponents ("authenticity is only a matter of opinion"). To resist this, we may need not only evidence, but a sense of moral value and political commitment. As Kundera understood, the real evil of kitsch lies not in aesthetics or logic but at the level of human vision. The main causes of long waits in casualty departments, or endemic over-eating in the UK, or people of working age abandoning hope and ambition, do not lie in the failings of the health service. They encompass chronic social inequality, the commoditisation of welfare, and a loss of communal generosity. If we fight against kitsch in medicine, we will be fighting against these.
Competing interests: None declared.

Postgrad Med J 2008;84:111-112. doi:10.1136/pgmj.2008.068031

\section{REFERENCES}

1. Layard $\mathbf{R}$. The case for psychological treatment centres. BMJ 2006:332:1030-2.

2. Kundera M. The unbearable lightness of being. New York: Perennial, 1999

\section{BMJ Clinical Evidence-Call for contributors}

BMJ Clinical Evidence is a continuously updated evidence-based journal available worldwide on the internet which publishes commissioned systematic reviews. BMJ Clinical Evidence needs to recruit new contributors. Contributors are healthcare professionals or epidemiologists with experience in evidencebased medicine, with the ability to write in a concise and structured way and relevant clinical expertise.

Areas for which we are currently seeking contributors:

- Secondary prevention of ischaemic cardiac events

- Acute myocardial infarction

- MRSA (treatment)

- Bacterial conjunctivitis

However, we are always looking for contributors, so do not let this list discourage you.

Being a contributor involves:

- Selecting from a validated, screened search (performed by in-house Information Specialists) valid studies for inclusion.

- Documenting your decisions about which studies to include on an inclusion and exclusion form, which we will publish.

- Writing the text to a highly structured template (about 1500-3000 words), using evidence from the final studies chosen, within 8-10 weeks of receiving the literature search.

- Working with BMJ Clinical Evidence editors to ensure that the final text meets quality and style standards.

- Updating the text every 12 months using any new, sound evidence that becomes available. The BMJ Clinical Evidence in-house team will conduct the searches for contributors; your task is to filter out high quality studies and incorporate them into the existing text.

- To expand the review to include a new question about once every 12 months.

In return, contributors will see their work published in a highly-rewarded peer-reviewed international medical journal. They also receive a small honorarium for their efforts.

If you would like to become a contributor for BMJ Clinical Evidence or require more information about what this involves please send your contact details and a copy of your CV, clearly stating the clinical area you are interested in, to CECommissioning@bmjgroup.com.

\section{Call for peer reviewers}

BMJ Clinical Evidence also needs to recruit new peer reviewers specifically with an interest in the clinical areas stated above, and also others related to general practice. Peer reviewers are healthcare professionals or epidemiologists with experience in evidence-based medicine. As a peer reviewer you would be asked for your views on the clinical relevance, validity and accessibility of specific reviews within the journal, and their usefulness to the intended audience (international generalists and healthcare professionals, possibly with limited statistical knowledge).

Reviews are usually 1500-3000 words in length and we would ask you to review between 2-5 systematic reviews per year. The peer review process takes place throughout the year, and our turnaround time for each review is 10-14 days. In return peer reviewers receive free access to BMJ Clinical Evidence for 3 months for each review.

If you are interested in becoming a peer reviewer for BMJ Clinical Evidence, please complete the peer review questionnaire at www.clinicalevidence.com/ceweb/contribute/peerreviewer.jsp 